V.A. Tsopa ${ }^{1}$, orcid.org/0000-0002-4811-3712,

S. I. Cheberiachko ${ }^{2}$, orcid.org/0000-0003-3281-7157, O.O. Yavorska ${ }^{2}$, orcid.org/0000-0001-5516-5310, V.V.Hilpert ${ }^{3}$, orcid.org/0000-0002-5996-5398, A.V.Yavorskyi ${ }^{2}$, orcid.org/0000-0003-4484-3723
1 - International Institute of Management, Kyiv, Ukraine

2 - Dnipro University of Technology, Dnipro, Ukraine, e-mail: elenayavorska80@gmail.com

3 - Ukrtsentrkadrylis, Boyarka, Ukraine

\title{
ELABORATION OF AN INTEGRAL SYSTEM OF COMPANY MANAGEMENT BY DEVELOPING CORPORATE AND SAFETY CULTURE
}

Purpose. To develop a model of the integrated system for company management, basing on the integration of the quality control and labour safety systems that differs from the known ones by combination of the processes based on the increase in the level of corporate safety cultures within a company.

Methodology. Formation of the basis for integration of the quality control and labour safety systems relies on the complex use of system analysis methods that, in combination with Deming and Shewhart cycle and with the performance of corresponding estimation and analysis of the organizational and safety cultures, help plan the practices, procedures, and resources for stage-bystage combination of the systems as well as maintain the obtained results.

Findings. An approach for efficient development of the integrated management system has been proposed on the basis of the analysis of levels of organizational and safety cultures; in future, this will help select such tools and practices that will allow having painless stage-by-stage combination of the available systems of quality control and labour safety with the substantiation of the necessary recourses. It has been established that a key element of the combination is readiness and motivation of not only top management but also linear management and ordinary workers to accept new technologies, approaches, and practices aimed at integration of those cultures, which is provided by the efficient staff involvement by means of corresponding training and constant communication to form the risk-oriented thinking.

Originality. A structure and model of the integrated system of quality and safety management as a unified interdependent mechanism have been proposed on the basis of the combination of organizational and safety cultures; that has allowed forming the unified principles for the development of a combined management system.

Practical value. The control parameters have been determined to identify stages of integration of the quality control and labour safety systems basing on the attitude to values and formed worldview as well as on the gaining the necessary competences by the workers.

Keywords: management system, quality, labour safety, Deming and Shewhart cycle

Introduction. Competitiveness is rather a topical problem that the management of any company faces. It is commonly known that basic methods for increasing competitiveness include the product quality improvement and loss reduction, which requires accurate and coordinated work of all the enterprise links, support of constant improvement of production technologies, logistics, benchmarking, management, personnel as well as organizational and safety cultures. The abovementioned is possible to be implemented by developing an integrated system of company management according to the requirements of international standards ISO. Such an integrated system helps combine different aspects within the organization basing on the risk management that makes it possible to reduce the material, financial, human, and organizational resources. However, while integrating the management systems, certain difficulties occur (differing objectives, structure, approach to problem solving, lack of common denominator, limited resources, misunderstanding and opposition of workers, growing complexity and number of procedures and so on) that sometimes prevent achieving the intended effects.

In its essence, the combination of the systems of quality control and labour safety according to the content of ISO 9001 and ISO 45001 is already an integration that is performed in terms of common use of Deming and Shewhart cycle (PDCA cycle) and similar requirements of Annex SL of ISO Guide 83:2012 to the management system standards (Fig. 1). Theoretically, while using general similarity of the approach, their integration is possible. However, due to considerable series of

(C) Tsopa V.A., Cheberiachko S. I., Yavorska O. O., Hilpert V. V., Yavorskyi A. V., 2021 important diversities in the sphere of application, their joint functioning is rather controversial. The quality management really contradicts the labour safety management. While making decisions on quality improvement, there arises a necessity in corresponding solutions concerning the intensification of labour safety; though, the latter needs both time for the implementation and, what is more important, additional costs. If the safety problems are ignored, certain contradiction occurs. Consider a theory of perspectives that helps understand the existence of certain biased attitude to the labour safety in terms of the quality purposes as the costs for labour safety are considered as the "one-time costs" and their "findings" are estimated as something ephemeral and time-spread. In other words, economic effect from the system of labour safety control at enterprises is expressed in terms of reduced financial losses of an enterprise that is subject to exponential dependence; it means that the results are represented temporally. Taking into consideration the company competitiveness as for the project financing, one can assume that it is better to invest money and get the immediate result than to invest and get some result in the long run; moreover, the result obtained is rather unknown. Each of the represented factors results in almost intuitive conclusion on the fact that the quality objectives will have good "attractiveness" and advantage over the labour safety needs. Thus, a topical task occurs as for the analysis of interrelations between different management systems to search for a model that will help unite the objectives within a hypothetic company.

Literature review. To develop an integration management system at an enterprise, several different approaches are proposed. The authors of paper [1] offer to use requirements for the product quality as the main principles of company man- 


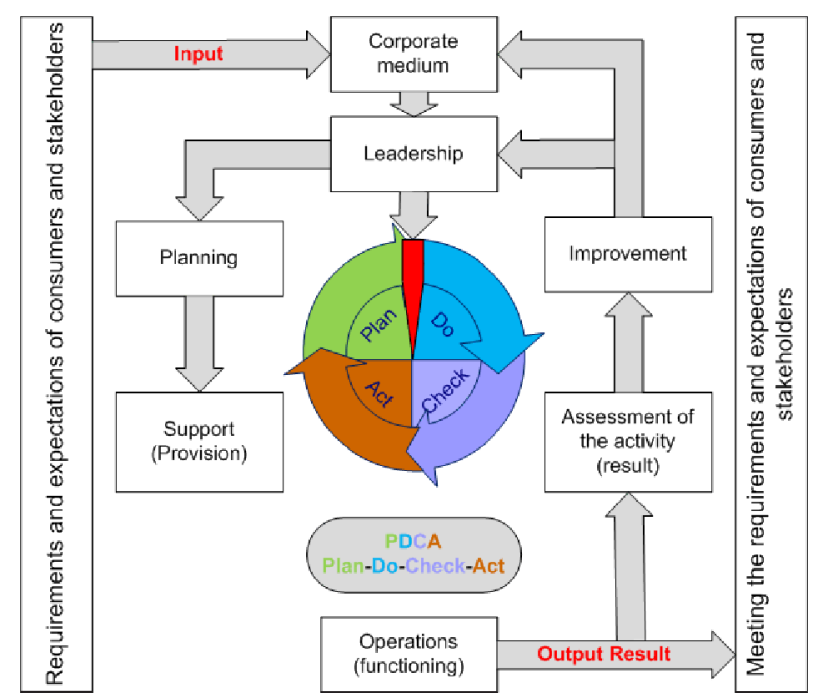

Fig. 1. Model of interrelation of the ISO standard divisions according to Annex SL of ISO Guide 83:2012 and Deming and Shewhart cycle

agement to be the integration basis. In this context, they use the IDEF0 (Integration Definition for Function Modeling) methodology [2] to construct that system. The authors of the next study [3] have similar ideas. However, the main principle to be the integration basis is the customer orientation. The authors consider that the requirements of the standard of $\mathrm{OH}$ SAS 18001 and ISO 14001 are quite easy to combine, and contradictions are easy to eliminate by correcting the corresponding processes of a quality management system. Contrary to the considered papers, the authors of publication [4] emphasize the available serious problems in the development of a combined management system that is in the identification of priorities. Unfortunately, according to the authors, they are different in each system, and their combination requires neglect of some aspects. Thus, the authors highlight that the majority of companies orient not towards the whole range of social and economic problems but select some specific trends. In most cases, it meets the consumer needs, which means the prevalence of quality indices over the safety ones; moreover, it is pointed out that OHSAS 18001 has no specific criteria for the efficiency assessment. By the way, a well-known approach "Hazard Analysis and Critical Control Points", whose performance is analysed in paper [5] can be used as the evaluation criteria of [6] a labour safety management system. On the other hand, it is possible to meet the contradicting requirements of the standards by gradual implementation of several management levels basing on the current tasks and complication of the processes occurring within the organization [7]. The idea is also close for the specialists who helped develop an integration management system at "Tambovenergo" [8]. They put an emphasis on the limitations resulting from different aspects of the company activity: corporate features, needs, nature, complexity of processes and so on. Such an approach is implemented at the machine-building enterprises. In this context, the priorities were identified according to the changes in both internal and external environment [9] basing on risk management [10]. A recommendation in paper [11] is of special interest; it means the development of a system for labour safety management in terms of ISO 9001 standard requirements while the quality control system is to be developed on the basis of ISO 4500. In this case, they are quite easy to be integrated. In terms of such an approach, it is quite important to identify the causeand-effect relations that will help understand the final objective of the formulated task. However, there is an idea that the combination of systems is possible only when the company authorities will be ready to hear about the labour safety problems, when the integrated system is to be developed not only for income increase but also for the search for new ways for company development, new possibilities and relations [12]. That is rather a complex process requiring both time and resources to understand the profit, develop a strategy, and perform corresponding evaluations. For instance, minimum four evolution levels are specified for the company: integration of documents, integration of tools, common policy and objectives, and common organizational culture [13]. The performed analysis demonstrates that nowadays the integration problem has not been solved so far; furthermore, it requires corresponding studies that will give a clear answer taking into account the stakeholders' interest: e.g. implementation of social responsibility (based on the ISO 26000 requirements) that can become the bridge uniting all the processes into one system.

The purpose of research is to propose a model of the integrated system of company management basing on the combination of quality control and labour security management.

Results. Certain solution for a formulated problem is seen in the necessity of obligatory accreditation of the system of labour safety management as a component of the general management system of a company. Then, it will be hard to solve the problems concerning the quality management by paying less attention to labour safety as they have certain similarities and differences (Table 1). However, in that case there is a hidden possibility of non-obtaining of financial income and, as a result, formalization of the performance of the tasks in hand concerning the labour safety improvement, whose solution is necessary only for the evidence base. At the same time, combination of the systems based on the integration of risks with the structure determined in Annex SL of ISO Guide 83:2012, which is developed to harmonize the requirements of different ISO standards in terms of the management system, has serious grounds for the practical implementation. It is interesting that the very term "integration of risk management at an organization" means dynamic and iterative process that takes into consideration the company's needs and culture. We believe that the latter is the key for the development of a unified management system for all the company processes. In other words, determination of the organizational culture and safety culture will help understand to what extent the company is ready for integration processes and propose those very mechanisms and approaches that will favour its further progress without serious image and financial losses, personnel opposition, and considerable increase in the additional load.

Thus, painless achievement of the identified goal is possible by elaborating the corresponding organizational and safety cultures that means the overall use of several strategies combining quality and labour safety.

For instance, that is possible to do by means of a modified Deming and Shewhart cycle (Fig. 2) that will be the basis for the "architecture" of the organizational and safety cultures, which will make it possible to identify key parameters of the integrated system and give the idea of further actions for the improvement of the integrated system management.

That statement is also based on the assumption concerning the interrelation between the level of organizational and safety cultures (Fig. 3), which results from the attitude to the values and worldview formed in the personnel.

According to the represented data, a key element to combine the management systems is represented by the ideas of the authorities that influence the corporate values and form certain worldview in the middle management determining the corporate culture. As we can see, the development strategies and technologies that are the safety core mostly depend on the interaction between the culture and quality rather than influence their development. In regard of the determined interrelations, we represent the safety culture as a metaphor - a bridge over a rapid wide river that is the cause of constant and numerous problems. In case of falling from the bridge, those are the unwanted losses of the company. It is no doubt that the bridge should be durable to provide proper connection. For this purpose, it is desirable to monitor 
Interrelation of the ideas and concepts of the target standards of a management system

\begin{tabular}{|c|c|c|}
\hline \multirow{2}{*}{ Division } & \multicolumn{2}{|r|}{ Standard } \\
\hline & ISO 9001 & ISO 45001 \\
\hline Management area & Quality & Health protection and labour safety \\
\hline Key objective & Increase in consumer satisfaction & $\begin{array}{l}\text { Improvement of the activity in the sphere of occupational health } \\
\text { and safety }\end{array}$ \\
\hline $\begin{array}{l}\text { Critical aspects } \\
\text { (focus points) }\end{array}$ & $\begin{array}{l}\text { Characteristics of the quality of products and } \\
\text { processes }\end{array}$ & Hazards related to the activity and operations of an enterprise \\
\hline $\begin{array}{l}\text { Intentions of the } \\
\text { management actions }\end{array}$ & $\begin{array}{l}\text { Processes critical for maintaining the characteristics } \\
\text { of product quality and general quality-related } \\
\text { company activity }\end{array}$ & $\begin{array}{l}\text { Activities and operations related to the identified and risks and } \\
\text { hazards for occupational health and safety }\end{array}$ \\
\hline $\begin{array}{l}\text { Results of incorrect } \\
\text { management }\end{array}$ & $\begin{array}{l}\text { Low productivity of an organization, low } \\
\text { efficiency, in particular, production output }\end{array}$ & Harm to health, life, and well-being of the corporate personnel \\
\hline Corporate risks & $\begin{array}{l}\text { Non-meeting the consumer demands and normative } \\
\text { demands. } \\
\text { Consequences: dissatisfaction of consumers, civil } \\
\text { and legal responsibility, criminal responsibility, } \\
\text { reduced market share, and financial losses }\end{array}$ & $\begin{array}{l}\text { Activity in the sphere of occupational health and safety and level of } \\
\text { management of occupational health and safety risks that do not } \\
\text { comply with the regulatory requirements or personnel requirements. } \\
\text { Consequences: criminal, civil and legal responsibility, loss of } \\
\text { labour force, and financial losses }\end{array}$ \\
\hline
\end{tabular}

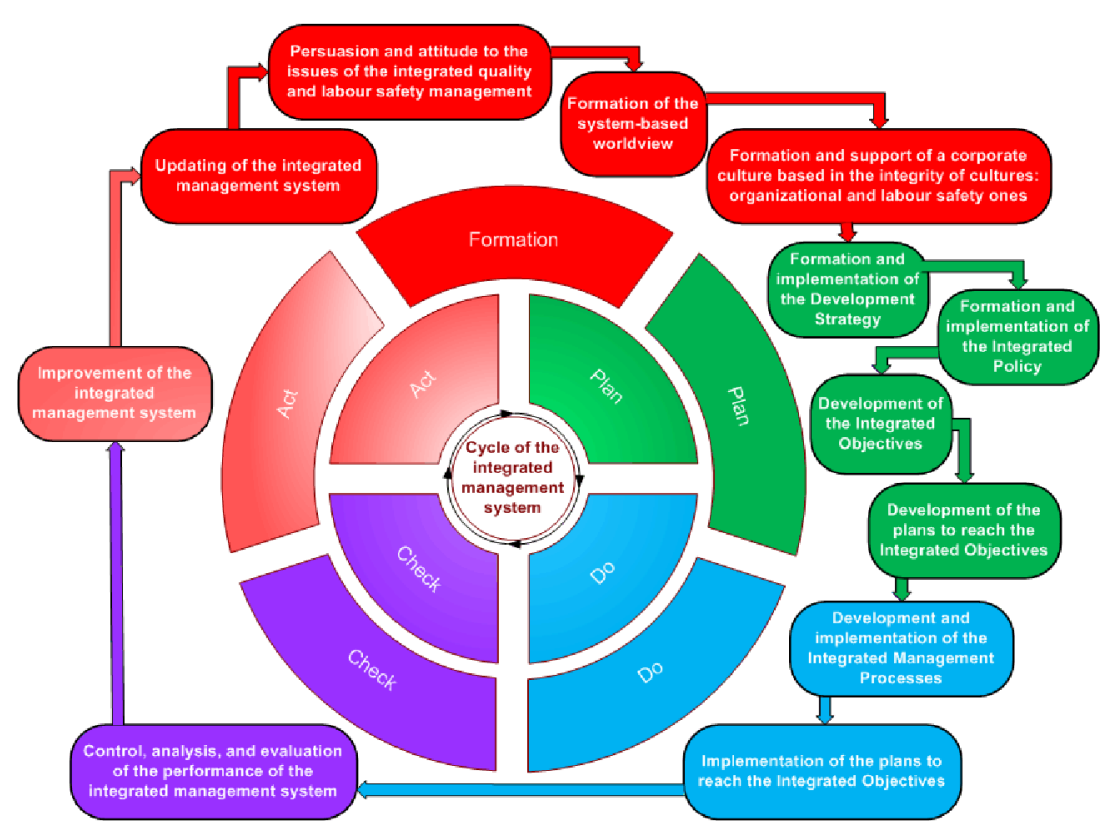

Fig. 2. Modified Deming and Shewhart (PDCA) cycle

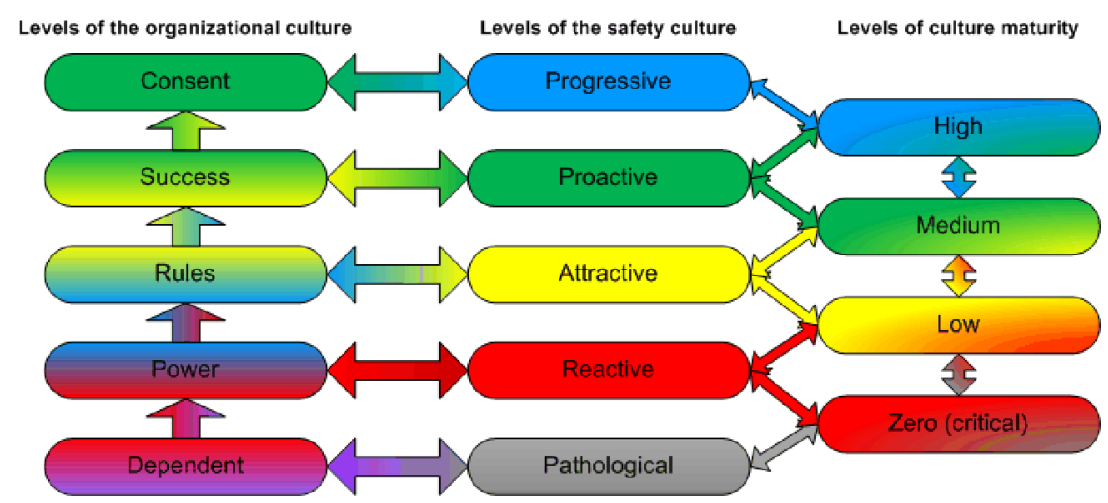

Fig. 3. Dependence of the safety culture level on the organizational culture

constantly its condition that will help detect timely possible problems (hazards) for their elimination. It is also important to implement the safety culture, which will favour the advent of leaders, formation of certain management system that will originate the required development strategies, promote the introduc- tion of innovative technologies, and form a management policy. The control parameters, which are to be identified according to the objectives, are an important element of such a culture. The control parameters can be characterized as certain level of maturity (Table 3 ) that will encourage for constant improvement. 
Example of the control parameters to monitor the level of development

\begin{tabular}{|c|c|c|c|c|}
\hline \multicolumn{5}{|c|}{ Level of the organizational culture } \\
\hline Dependent & Power & Rules & Success & Consent \\
\hline \multicolumn{5}{|c|}{ Identification of objectives } \\
\hline $\begin{array}{l}\text { Little information on the } \\
\text { activity aimed at provision } \\
\text { of quality and safety. } \\
\text { Formal objective and tasks } \\
\text { of the system, performance } \\
\text { indicators are not } \\
\text { identified let alone their } \\
\text { documenting. Lack of } \\
\text { clear functional duties of } \\
\text { the management structure }\end{array}$ & $\begin{array}{l}\text { Objectives in the system are } \\
\text { based on constant } \\
\text { improvement of the } \\
\text { parameters and statistics for } \\
\text { the previous year. There are } \\
\text { functional barriers between } \\
\text { subdivision and employees. } \\
\text { Imperfect system of } \\
\text { performance assessment that } \\
\text { favours the situation when } \\
\text { the subdivision heads defend } \\
\text { the local objectives }\end{array}$ & $\begin{array}{l}\text { Constant process of } \\
\text { identifying the objectives } \\
\text { aimed at the improvement } \\
\text { of procedures and } \\
\text { systems. A strategy for the } \\
\text { company development is } \\
\text { elaborated. Best practices } \\
\text { of the corporate culture } \\
\text { are being accumulated. } \\
\text { Implementation of the } \\
\text { system for assessing } \\
\text { satisfaction }\end{array}$ & $\begin{array}{l}\text { Company management } \\
\text { participates constantly in } \\
\text { the identification of } \\
\text { objectives; to accelerate } \\
\text { the process, the authorities } \\
\text { delegate powers for the } \\
\text { lower levels. Corporate } \\
\text { values are focused on team } \\
\text { work and development of } \\
\text { human potential. A } \\
\text { programme for the } \\
\text { company development is } \\
\text { elaborated }\end{array}$ & $\begin{array}{l}\text { Each employee is } \\
\text { responsible for specific } \\
\text { risk-control measures. } \\
\text { Roles and actions are } \\
\text { clearly identified for all } \\
\text { the levels. Working teams } \\
\text { are independent in } \\
\text { setting their working } \\
\text { goals. A system of } \\
\text { motivation is developed } \\
\text { on the basis of } \\
\text { partnership relations }\end{array}$ \\
\hline \multicolumn{5}{|c|}{ Monitoring and accountability } \\
\hline $\begin{array}{l}\text { There is no responsibility } \\
\text { as no objectives are } \\
\text { identified }\end{array}$ & $\begin{array}{l}\text { Accountability is poor; } \\
\text { progress is insignificant, it is } \\
\text { analysed during the year }\end{array}$ & $\begin{array}{l}\text { Constant monitoring of } \\
\text { the parameters. } \\
\text { Accountability is shared } \\
\text { by the departments }\end{array}$ & $\begin{array}{l}\text { Linear managers and } \\
\text { heads are responsible for } \\
\text { the results. Initiatives/ } \\
\text { measures are supported } \\
\text { adequately with the } \\
\text { resources; plans/ } \\
\text { objectives of the actions } \\
\text { are set and controlled }\end{array}$ & $\begin{array}{l}\text { The performance } \\
\text { parameters are } \\
\text { preventive; a system of } \\
\text { performance monitoring } \\
\text { is aimed at the } \\
\text { improvement of work }\end{array}$ \\
\hline
\end{tabular}

To achieve success, it is necessary to select a complete set of principles (Table 4). The following principles are considered to be the most efficient ones:

1. Development and implementation of a comprehensible labour safety and health protection programme that means increasing awareness of employers in terms of safety by means of various procedures, meetings, trainings, disciplinary and motivation policy.

2. Being sure of keeping within the legislative requirements as for the necessity of constant improvement of labour conditions, safety of technological equipment, technological lines, medical service, etc.

3. Assurance of the increasing occupational safety level by automation of industrial process, use of blocking devices, update of the workplace ergonomics, implementation of the user-friendly interface to control the equipment, and so on.
4. Leadership in safety that will change the management system from the command and hierarchical models to more democratic ones that are kept by means of horizontal relations, having more decision-making flexibility.

5 . Risk control in quality and labour safety.

6. Behavioural safety is the most questionable strategy that will improve the safety level at the expense of changes in the organization of a production processes that will influence the personnel behaviour.

Discussion. While analysing the main principles being the basis for the formation of organizational and safety cultures within a company (Table 5) and effecting both quality and level of staff protection, one can note a lot of rather similar elements that can become the basis for the elaboration of the integrated management system.

The approach differs in the fact that such combination is authorized by the staff itself from the lower level, not by the top

Table 3

Fragment of the control parameters to identify a maturity level of the organizational and safety cultures within a company

\begin{tabular}{|c|c|c|c|c|}
\hline \multirow{2}{*}{ Question } & \multicolumn{3}{|c|}{ Answer } & \multirow{2}{*}{ What should be done for the improvement? } \\
\hline & Yes & No & Sometimes & \\
\hline How often are the meetings held? & & & Sometimes & To hold target meetings to discuss the arising problems \\
\hline $\begin{array}{l}\text { Is there any risk assessment to substantiate the } \\
\text { safe measures? }\end{array}$ & Yes & & & \\
\hline $\begin{array}{l}\text { Are you provided with the comprehensible } \\
\text { safety instructions with risk assessment? }\end{array}$ & Yes & & & \\
\hline $\begin{array}{l}\text { Are you provided with the trainings to learn safe } \\
\text { methods of work performance? }\end{array}$ & Yes & & & \\
\hline Do you discuss the causes of accidents? & & & Sometimes & $\begin{array}{l}\text { It is necessary to monitor regularly the accident causes and develop } \\
\text { certain measures aimed at maintaining labour safety at workplaces }\end{array}$ \\
\hline $\begin{array}{l}\text { Are the workers encouraged to improve the } \\
\text { operating processes? }\end{array}$ & & No & & To develop and implement an incentive scheme for the personnel \\
\hline Are the new safety procedures implemented? & & & Sometimes & $\begin{array}{l}\text { To analyse constantly safety procedures and implement them at } \\
\text { an enterprise }\end{array}$ \\
\hline $\begin{array}{l}\text { If the tasks concerning the improvement of } \\
\text { operating processes identified during previous } \\
\text { meeting are reconsidered? }\end{array}$ & Yes & & & \\
\hline
\end{tabular}


management, by implementing new improved standards [14]. Though, their implementation helps be rather competitive. Certainly, the process is rather long and requires corresponding work involving the staff training, formation of corresponding values and worldview that is mentioned before. Similar conclusions were represented in the work by Juliusz Piwowarski where it is stated that the culture improvement is possible only by the staff development supported by motivation [15]. The conclusion does not also contradict the studies showing that both organizational and safety cultures are the components of the overall corporate culture (Fig. 4) [16].

Taking into consideration the mentioned approach, we can state that the development of the integrated management system is possible basing on the combination of the cultured formed at some enterprise [17]. In this context, at the first stage, it is desirable to identify the level of their development; further, one should propose a corresponding approach for the combination that will meet the principles of formation of an overall corporate culture.

Conclusions. An approach has been proposed for efficient development of the integrated management system on the basis of the studies on the levels of organizational and safety cultures; in future, that will help select the tool for painless stage-by-stage combination of the available systems of quality control and labour safety. An important element is the readiness of the top management, linear management, and ordinary workers to accept new technologies, approaches, and practices aimed at integration of those cultures. The structure and model of the integrated system of quality and safety management as the integral interdependent mechanism basing on the combination of organizational and safety cultures have been proposed; that made it possible to form the unified principles for the development of the united management system. The control parameters have been identified, and

Principles of the integrated management system

\begin{tabular}{|c|c|}
\hline Principle & Characteristics \\
\hline $\begin{array}{l}\text { Balance of the } \\
\text { stakeholders' } \\
\text { interest }\end{array}$ & $\begin{array}{l}\text { Long-term success depends on understanding, satisfaction, and prediction of current and future needs and expectations of } \\
\text { consumers as well as on understanding and consideration of the needs and expectations of other interested parties. A } \\
\text { company should strive for ensuring the balance between the interests by setting and reaching the corresponding goals, } \\
\text { which take into consideration the requirements of all the interested parties as for the loss reduction }\end{array}$ \\
\hline $\begin{array}{l}\text { Leadership of the } \\
\text { company } \\
\text { authorities }\end{array}$ & $\begin{array}{l}\text { The authorities provide the uniformity of the objectives and branch of the company activity. They should possess } \\
\text { leadership skills and demonstrate actively their being stick to the ideology of the integrated management system aimed at } \\
\text { achieving the shared company objectives. The company authorities should create and support the internal environment } \\
\text { where the staff can be involved completely in the solution of problems and reaching the shared goals }\end{array}$ \\
\hline $\begin{array}{l}\text { Involvement of } \\
\text { the personnel }\end{array}$ & $\begin{array}{l}\text { All-level workers are the company basis, its main resource and value. Continuous identification of the training needs, } \\
\text { development of competence, increasing of motivation, and showing care about the staff are the conditions of profitable use } \\
\text { of the workers' ability to meet the specified requirements and reach the planned results aimed at costs reduction }\end{array}$ \\
\hline $\begin{array}{l}\text { Compliance with } \\
\text { the legal and other } \\
\text { requirements }\end{array}$ & $\begin{array}{l}\text { Requirements for the integrated systems are additional (but not alternative) as for certain technical and contract conditions } \\
\text { for the products or services, legal requirements as well as other requirements, with which a company agrees (i.e. which it } \\
\text { starts following) }\end{array}$ \\
\hline $\begin{array}{l}\text { Approach based } \\
\text { on the risk } \\
\text { management }\end{array}$ & $\begin{array}{l}\text { Any company functions in terms of the effect of different internal and external factors on its activity, which affects the } \\
\text { degree of its achieving the objectives. Risk management makes it possible to use profitably positive possibilities and } \\
\text { minimize the probability of the occurrence of hazardous events resulting in certain losses }\end{array}$ \\
\hline $\begin{array}{l}\text { Process-based } \\
\text { approach }\end{array}$ & $\begin{array}{l}\text { To reach the specified goals effectively, the authorities should make the experts understand the essence of the work under } \\
\text { performance, identify the activity types that give the added value, provide them with the corresponding resources, and } \\
\text { implement them under the controlled conditions }\end{array}$ \\
\hline $\begin{array}{l}\text { System-based } \\
\text { approach }\end{array}$ & $\begin{array}{l}\text { The company authorities should use the integrated management system as a key tool to reach the goals. In its turn, the } \\
\text { integrated management system is considered as a complex of interrelated processes, whose management is performed for } \\
\text { constant improvement in term of a common "plan - do - check - act" method of Deming cycle }\end{array}$ \\
\hline $\begin{array}{l}\text { Approval of the } \\
\text { fact-based } \\
\text { solutions }\end{array}$ & $\begin{array}{l}\text { Activity of the authorities at different organization levels is tightly connected with the approval of managerial decisions. The } \\
\text { efficiency of those decisions is based on the understanding of peculiarities of the conditions of internal and external environments } \\
\text { at the decision-approval moment as well as on the system analysis of the company activity, features of the situations and } \\
\text { alternatives that is possible only basing on the analysis of the overall and unbiased data concerning the activity results }\end{array}$ \\
\hline $\begin{array}{l}\text { Constant } \\
\text { improvement }\end{array}$ & In general, constant improvement of the company activity should be considered as its unchangeable objective \\
\hline
\end{tabular}

Comparison of the main principles of the organizational and safety cultures

\begin{tabular}{|l|l|}
\hline \multicolumn{1}{|c|}{ Organizational culture } & \multicolumn{1}{c|}{ Safety culture } \\
\hline The workers' awareness of the tasks to provide and improve quality & The workers' awareness of the tasks to provide and improve labour safety \\
\hline $\begin{array}{l}\text { Formation of the workers' competences as for ensuring } \\
\text { corresponding quality }\end{array}$ & $\begin{array}{l}\text { Formation of the workers' skills as for the safe performance of } \\
\text { production assignments }\end{array}$ \\
\hline $\begin{array}{l}\text { Commitment of the company management and workers to all the } \\
\text { types of activity aimed at constant quality improvement and } \\
\text { maintaining }\end{array}$ & $\begin{array}{l}\text { Commitment of the company management and workers to the formation } \\
\text { of safe working conditions by constant highlighting of the priority of safety }\end{array}$ \\
\hline $\begin{array}{l}\text { Constant monitoring in terms of quality parameters, auditing, } \\
\text { implementation of different correcting and preventive measures }\end{array}$ & $\begin{array}{l}\text { Constant monitoring in terms of quality parameters, auditing, } \\
\text { implementation of different correcting and preventive measures }\end{array}$ \\
\hline $\begin{array}{l}\text { Development and support of the incentive schemes to support } \\
\text { meeting of the quality-related rules, requirements, and instructions }\end{array}$ & $\begin{array}{l}\text { Implementation of the incentive schemes to support meeting of the } \\
\text { labour safety rules, requirements, instructions }\end{array}$ \\
\hline $\begin{array}{l}\text { Implementation of the responsibility for high-quality activity by } \\
\text { official obligations to follow duty regulations }\end{array}$ & $\begin{array}{l}\text { Implementation of the safety-related responsibility by official } \\
\text { obligations to follow duty regulations }\end{array}$ \\
\hline
\end{tabular}




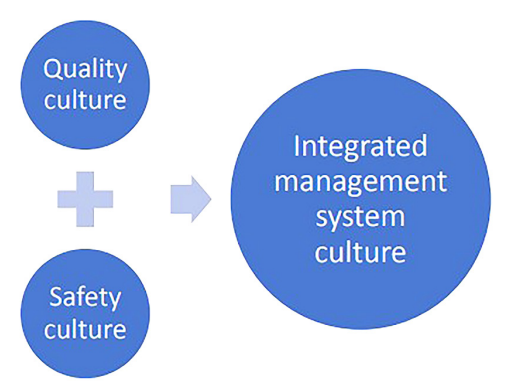

Fig. 4. Formation of the corporate culture within the combination of organizational and safety cultures

the modified Deming and Shewhart (PDCA) cycle has been offered. That helped identify the stages of combination of the quality and labour safety systems, which are based on the attitude to the values and worldview formed in the workers.

Acknowledgements. This work was supported by the Ministry of Education and Science of Ukraine, "Geotechnological basics of the formation of energochemical complexes of coalmining regions" (grant No. 0120U102084).

\section{References.}

1. Golubenko, O. A., \& Poglazova, Ye. N. (2017). What is an integrated management system (IMS)? Symbol of Science, (04-2), 65-68. Retrieved from https://cyberleninka.ru/article/n/chto-takoe-integrirovannaya-sistema-menedzhmenta-ism

2. Pereverzev, P. P. (2012). Functional modeling of the production engineering processes at the machine-building enterprises. Current problems of science and education, (2), 1-9. Retrieved from http://www. science-education.ru/ru/article/view?id=6004.

3. Chernov, V.A., \& Tikhova, A. D. (2018). Integrated management of the sustainable development: methodological prerequisites and their practical implementation. A world of new economy, 12(1), 92-103. https://doi.org/10.26794/2220-6469-2018-12-1-92-103.

4. Telnov, A. S., \& Reshmidilova, S. L. (2014). Tendencies and contradictions of the development of integrated quality management systems. Bulletin of Khmelnytsky National University, 5(2), 149-155. Retrieved from http://elar.khnu.km.ua/jspui/bitstream/123456789/4007/1/Vchnu_ekon_2014_5\%282\%29_35.pdf.

5. Vodiankina, L. D., \& Kutarenko, N. Ya. (2013). Prospects of the implementation of the HAICCP (hazard analysis and identification of critical control points) system during the food production. Regional economy, (1), 185-194. Retrieved from http://econom.chnu.edu.ua/ wp-content/uploads/2016/11/kutarenko-4.pdf.

6. Dychkovskyi, R. O., Avdiushchenko, A. S., Falshtynskyi, V. S., \& Saik, P. B. (2013). On the issue of estimation of the coal mine extraction area economic efficiency. Naukovyi Visnyk Natsionalnoho Hirnychoho Universytetu, (4), 107-114.

7. Smirnova, K. V. (2012). Integrated management systems: practices, problems, and prospects of their development in Ukraine. Bulletin of Odesa State Environmental University, 13, 50-61.

8. Poltronieri, C. F., Gerolamo, M.C., \& Carpinetti, L. C. R. (2017). An instrument for the assessment of management systems integration, Gestão \& Produção, 24(4), 638-652. https://doi.org/10.1590/0104-530x1697-14. 9. Maiera, D., Vadastreanu, A. M., Kepplerc, T., Eidenmullerd, T., \& Maiere, A. (2015). Innovation as a part of an existing integrated management system. Procedia Economics and Finance, 26, 1060-1067. https://doi.org/10.1016/S2212-5671(15)00930-2.

10. Ketschau, T.J. (2017). A Conceptual Framework for the Integration of Corporate Social Responsibility and Human Resource Development Based on Lifelong Learning. Sustainability, 9(9), 1545. https://doi.org/10.3390/su9091545.

11. Domingues, P., Sampaio, P., \& Saraiva, P. (2012). Management Systems: Integration or Addition. International Journal of Quality \& Reliability Management, 29(4), 402-424. https://doi. org/10.1108/02656711211224857.

12. Gianni, M., \& Gotzamani, K. (2014). Management systems integration: lessons from an abandonment case. Journal of Cleaner Production, 86, 265-276. https://doi.org/10.1016/j.jclepro.2014.08.023. 13. Golovchenko, A., Dychkovskyi, R., Pazynich, Y., Edgar, C. C., Howaniec, N., Jura, B., \& Smolinski, A. (2020). Some Aspects of the Control for the Radial Distribution of Burden Material and Gas Flow in the Blast Furnace. Energies, 13(4), 923. https://doi.org/10.3390/en13040923.
14. Gornostayev, S. S. (2000). Origin of Platinum-Bearing Placers in the Aluchin Horst, Russian Far East. Economic Geology, 95(3), 549558. https://doi.org/10.2113/95.3.549.

15. Kuchmieiev, O. O. (2017). An integrated system to manage commercial risks of trade enterprises. Scientific notes of "KROK" University (Economic Sciences), 48, 113-121. https://doi.org/10.31732/26632209-2017-48-113-121.

16. Tsopa, V.A. (2019). Integration of the systems to manage losses related to human life and health at production site basing on risk management and ISO 45001:2018. Collection of papers "Risk control in the systems of labour safety and hygiene management: theory and practice", (pp. 21-35). Kyiv.

17. Bal-Prylypko, L.V., \& Nikolaienko, M.S. (2018). Integrated system of quality and safety control for food products. Bioresources and natural management, 10(5-6), 68-76.

\section{Побудова інтегрованої системи управління компанією шляхом розвитку корпоративної культури безпеки}

\author{
В. А. Цопа ${ }^{1}$, С. I. Чеберячко ${ }^{2}$, О. О. Яворська ${ }^{2}$, \\ В. В. Гільперт ${ }^{3}$, А. В. Яворський ${ }^{2}$
}

1 - Міжнародний інститут менеджменту, м. Київ, Україна 2 - Національний технічний університет «Дніпровська політехніка», м. Дніпро, Україна, e-mail: elenayavorska80@ gmail.com

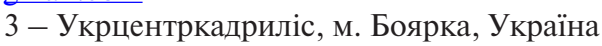

Мета. Розробити модель інтегрованої системи управління компанією на основі поєднання системи управління якістю та безпеки праці, що відрізняється від відомих поступовим поєднанням процесів, які базуються на дослідженні рівня корпоративної культури безпеки в компанії.

Методика. Формування основи для інтеграції систем управління якістю й безпекою праці побудовано на комплексному використанні методів системного аналізу, що в поєднанні з циклом Шухарта-Демінга, із проведенням відповідної оцінки та аналізу організаційної культури й культури безпеки, дозволяє спланувати практики, процедури та ресурси для поетапного поєднання систем і перегляду й підтримки вже досягнутих результатів.

Результати. Запропоновано підхід для ефективної побудови інтегрованої системи управління на основі дослідження рівня організаційної культури й культури безпеки, що дозволить у подальшому підібрати такі інструменти та практики, які дозволять безболісно поетапно провести поєднання існуючих систем управління якості й безпеки праці з обгрунтуванням необхідних ресурсів. Установлено, шо ключовим елементом до поєднання є готовність і вмотивованість як найвищого керівництва, лінійного менеджменту, так і звичайних працівників до сприйняття нових технологій, підходів і практик, направлених на інтеграцію цих культур, що забезпечується ефективним залученням персоналу через відповідне навчання, постійне спілкування для формування ризик-орієнтованого мислення.

Наукова новизна. Запропонована структура й модель інтегрованої системи управління якістю та безпекою в єдиний взаємозалежний механізм на основі поєднання організаційної культури та культури безпеки, що дозволило сформувати уніфіковані принципи для побудови об'єднаної системи управління.

Практична значимість. Визначені контрольні показники, що дозволяють визначити етапи поєднання систем якості й безпеки праці, які витікають із відношення до цінностей і сформованого світогляду та набуття необхідних компетенцій у працівників.

Ключові слова: система управління, якість, безпека праці, цикл Шухарта-Демінга

Recommended for publication by V.I. Golinko, Doctor of Technical Sciences. The manuscript was submitted 18.12.20. 